ZEN AND COMPARATIVE STUDIES 
Also by Masao Abe

BUDDHISM AND INTERFAITH DIALOGUE: Part One of

a two-volume sequel to Zen and Western Thought

THE EMPTYING GOD: A Buddhist-Jewish-Christian Conversation (co-author with seven theologians)

KITARŌ NISHIDA: An Inquiry into the Good (co-translator with Christopher Ives)

A STUDY OF DŌGEN: His Philosophy and Religion ZEN AND WESTERN THOUGHT

A ZEN LIFE: D. T. Suzuki Remembered (editor)

Also edited by Steven Heine

A BLADE OF GRASS: Japanese Poetry and Aesthetics in Dōgen Zen BUDDHISM AND INTERFAITH DIALOGUE by Masao Abe (editor) DŌGEN AND THE KŌAN TRADITION: A Tale of Two Shōbōgenzō Texts

A DREAM WITHIN A DREAM: Studies in Japanese Thought EXISTENTIAL AND ONTOLOGICAL DIMENSIONS OF TIME IN HEIDEGGER AND DŌGEN

JAPAN IN TRADITIONAL AND POST-MODERN PERSPECTIVES (co-editor with Charles Wei-hsun Fu)

A STUDY OF DŌGEN: His Philosophy and Religion

by Masao Abe (editor) 


\title{
Zen and Comparative Studies
}

Part two of a two-volume sequel to Zen and Western Thought

\author{
Masao Abe \\ Professor Emeritus \\ Nara University of Education, Japan \\ Edited by Steven Heine \\ Associate Professor of Religious Studies \\ Pennsylvania State University
}




\section{2}

(C) Masao Abe 1997

Softcover reprint of the hardcover 1st edition 1997 978-0-333-6I 199-9

All rights reserved. No reproduction, copy or transmission of this publication may be made without written permission.

No paragraph of this publication may be reproduced, copied or transmitted save with written permission or in accordance with the provisions of the Copyright, Designs and Patents Act 1988, or under the terms of any licence permitting limited copying issued by the Copyright Licensing Agency, 90 Tottenham Court Road, London WIP 9HE.

Any person who does any unauthorised act in relation to this publication may be liable to criminal prosecution and civil claims for damages.

The author has asserted his rights to be identified as the author of this work in accordance with the Copyright, Designs and Patents Act 1988.

First published 1997 by

MACMILLAN PRESS LTD

Houndmills, Basingstoke, Hampshire RG21 6XS

and London

Companies and representatives

throughout the world

ISBN 978-1-349-39227-8

ISBN 978-0-230-37599-4 (eBook)

DOI $10.1057 / 9780230375994$

A catalogue record for this book is available from the British Library.

This book is printed on paper suitable for recycling and made from fully managed and sustained forest sources.

$\begin{array}{rrrrrrrrrr}10 & 9 & 8 & 7 & 6 & 5 & 4 & 3 & 2 & 1 \\ 06 & 05 & 04 & 03 & 02 & 01 & 00 & 99 & 98 & 97\end{array}$




\section{Contents}

Foreword

vii

Preface

00

PART ONE FUNDAMENTALS OF ZEN

1 Zen and Buddhism

2 The Core of Zen: The Ordinary Mind is Tao

3 'Life and Death' and 'Good and Evil' in Zen

4 Emptiness

5 God, Emptiness, and the True Self

6 The Concept of Self as Reflected in Zen Buddhist Literature

7 Education in Zen

PART TWO ZEN, BUDDHISM, AND WESTERN THOUGHT

8 Substance, Process, and Emptiness: Aristotle, Whitehead and Zen

9 The Problem of Death in East and West: Immortality, Eternal Life, Unbornness

10 Śūnyatã as Formless Form: Plato and Mahāyāna Buddhism

11 The Self in Jung and Zen

PART THREE CURRENT ISSUES IN BUDDHISM

12 Time in Buddhism 
13 On the Occasion of Buddha Day 1990:

The Future Task of Buddhism

14 Transformation in Buddhism

15 Religious Tolerance and Human Rights:

A Buddhist Perspective

PART FOUR ZEN AND JAPANESE CULTURE

16 Shinto and Buddhism: The Two Major Religions of Japan

17 Zen in Japan

232

18 The Japanese View of Truth

Notes

251

Index 


\section{Foreword}

\section{Steven Heine}

This is the second volume of a two-volume sequel to the awardwinning Zen and Western Thought (1985) by Masao Abe, the leading exponent of Japanese Buddhism in the West since the death of D. T. Suzuki and one of the major contemporary representatives of the Kyoto School of Japanese philosophy founded by Nishida Kitarō. At the time of the publication of the original volume, Abe had for twenty years been lecturing at numerous American universities, including Chicago, Columbia, Princeton, Hawaii, and Claremont, and publishing in a variety of English-language journals of Buddhist studies and comparative religions, including Buddhist-Christian Studies, The Eastern Buddhist, International Philosophical Quarterly, Japanese Religions, Journal of Chinese Philosophy, Numen, Philosophy East and West, and Scottish Journal of Religious Studies, among many other scholarly outlets.

The central purpose underlying the collection of essays in Zen and Western Thought, edited by William R. LaFleur, is a clarification of the authentic spirit of Zen in light of the history of Buddhist thought and through critical comparisons with Western philosophy and religion. The book is divided into four parts: Zen and Its Elucidation; Zen, Buddhism, and Western Thought; Three Problems in Buddhism; and Religion in the Present and the Future. In each part, Abe draws on the Mahāyāna doctrine of emptiness (śūnyatā) as expressed in a uniquely spontaneous, paradoxical fashion by classical Zen masters such as Lin-chi, Chao-chou, and Dōgen as well as his own mentor Hisamatsu Shin'ichi. Abe refutes several common misconceptions, including the views that Zen represents an anti-intellectualism or nihilism, and he contrasts the Zen approach to emptiness with the notions of Western philosophers which seem quite similar, such as Nietzsche's creative nihilism, Whitehead's process philosophy, and Tillich's 'courage to $b^{\prime}$ in the face of non-being. Through a comparative methodology, Abe constructs Zen philosophy as a spiritual foundation for humanity facing a critical turning point in history. He carefully explains that the notion of emptiness is not merely a form of negation in contrast to affirmation but a 'double negation' that negates and thereby surpasses the polarity between affirmation and negation. 
Emptiness thus serves as a basis for a radical realism and a compassionate way of life which can function as a new dynamic and flexible cosmology for the global age.

After the publication of Zen and Western Thought, Abe published several volumes, including: his editing of a collection of essays in remembrance of D. T. Suzuki (D. T. Suzuki: A Zen Life Remembered, 1986); a translation with Christopher Ives of Nishida's first work (Kitaro Nishida: An Inquiry into the Good, 1990); his serving as the main contributor for a collection of essays on interfaith dialogue with eminent Western theologians (The Emptying God: A Buddhist-JewishChristian Conversation, 1990, edited by Ives and John Cobb); and his collected papers on Dōgen's philosophy of time, Buddha-nature, and the oneness of practice-attainment in comparison with Heidegger and Shinran (A Study of Dögen: His Philosophy and Religion, 1992, edited by Steven Heine). As this is going to press, Abe is scheduled to publish a collection of his lectures in Japanese for the FAS Society, 'Kongen kara no shuppatsu' (Departure from the Root-source), and a sequel to The Emptying God entitled Divine Emptiness and Historical Fullness: A Buddhist-Jewish-Christian Conversation with Masao Abe edited by Ives. Also, Donald Mitchell is compiling an anthology, Masao Abe: His Life of Dialogue,' which will be a record of his dialogical activities in Japan and the West for the past four decades.

When Abe and I began planning the sequel to Zen and Western Thought at the request of Professor John Hick and Macmillan, we quickly realized that there was simply too much valuable material to contain in a single volume and we decided that it should be divided instead into several volumes. (In addition to the two-volume sequel, Abe is preparing a third volume, A Study of the Philosophy of the Kyoto $S c h o o l$, edited by James Fredericks, which will contain his explications and interpretations of Nishida and Hisamatsu as well as Tanabe Hajime and Nishitani Keiji.) The first sequel, Buddhism and Interfaith Dialogue (1995), highlights Abe's participation in continuing ideological encounter and dialogue with a number of the most prominent Western theologians of the last half of the twentieth century representing a wide range of positions, including existential, mystical, process, kenotic, liberation and feminist theologies. The first and still the most important figure with whom Abe engaged in dialogue was Paul Tillich, the focus of one of the three sections in the volume. The remainder of the volume contains the record of his remarkable exchanges with Thomas Altizer, John Cobb, John Egan, Langdon Gilkey, Paul Knitter, Hans Küng and Marjorie Suchocki. 
According to Abe, the forces of modernization, secularization and technologization continue to undermine traditional forms of religiosity while at the same time compelling a vibrant, mutually challenging encounter between Buddhism and Christianity, East and West, in pursuit of a universal and unifying global ideology that is also faithful to the integrity and the innate dissimilarities between the respective traditions.

The current volume returns to the basic structure and methodology of Zen and Western Thought in exploring the fundamentals of Zen religious experience, Zen and Western philosophy, current methodological issues in Zen studies, and the relation between Zen and Japanese culture and spirituality. Part One demonstrates the historical and ideological connections between Śākyamuni's basic doctrine of dependent co-origination and the Mahayanana notion of emptiness, particularly as expressed in the Mādhyamika school and the Prajūappa aramitā Sütras, which serve as the background for the Zen view of Nirvanna realized in each and every impermanent moment (setsuna-soku-nehan). Abe contrasts the Zen experiential approach to emptiness with Western monotheistic notions of an objectifiable, transcendental theology which tend to generate dualities, and he stresses how Zen is based on an intensely subjective realization of Awakening, which overcomes polarities between knowing and speaking, living and dying, being and non-being, good and evil, the momentary and continuity, natural and supernatural and Nirvāna and samsāra.

The second part critically explores affinities and divergences with Western thinkers from Plato and Aristotle to Whitehead and Jung, each of whom in his own way tends to privilege being, substance, eternity, and enduring selfhood in contrast to the Zen emphasis on emptiness, insubstantiality, impermanence, and selflessness. Part Three, greatly influenced by Hisamatsu's philosophy of the FAS movement, demonstrates that Zen is neither a museum curiosity nor a disengaged method of contemplation. Rather, Zen, if properly interpreted, offers a viable approach for resolving contemporary social problems by virtue of the Bodhisattva's compassionate sense of commitment and responsibility based on the non-duality of self and world. In a historical era defined by pluralism, the flexibility of Zen's non-sustantive, non-dualistic philosophy can function as a paradigm for a tolerant, open-ended discourse required of all ideologies, whether religious, philosophical, scientific, or secular, seeking to overcome dogmatic, one-sided insistence. 
Finally, Part Four examines the development of Zen in the context of Japanese religiosity marked by an interplay and syncretism between Buddhism and Shinto from the time Shotoku Taishi introduced Buddhism into Japan through the development of the Kyoto School. In particular, Abe shows how Zen's formation in Japan during the Kamakura era in which samurai culture came to be dominant gave rise to a different approach emphasizing both ascetic discipline and aesthetic expression than is found in the $\mathrm{Ch}^{\prime}$ an school in Sung China. It this section, as throughout the book and indeed his entire oeuvre, Abe makes a twofold plea for a better understanding of Zen on the part of the West and for an enhanced approach by Zen based on a critical self-reflective stance inspired by its encounter with the West.

\section{ACKNOWLEDGMENTS}

The material in this volume was originally written or presented in a variety of journals or at conferences. The following list explains the initial appearance of each chapter:

Chapter 1, 'Zen and Buddhism', appeared in The Eastern Buddhist, 26/1 (1993), pp. 26-49, based on a paper delivered as the Charles Gooding Lecture at the Divinity School of the University of Chicago in 1969 and edited with the assistance of W.S. Yokoyama. The author is indebted to Hisamatsu Shin'ichi's essay, 'Zen: Its Meaning for Modern Civilization,' The Eastern Buddhist, vol. 1, no. 1 (1965).

Chapter 2, 'The Core of Zen: The Ordinary Mind is Tao', was previously unpublished.

Chapter 3, "Life and Death" and "Good and Evil" in Zen', appeared in Criterion, 9/1 (1969), pp. 7-11, based on a paper delivered as the Charles Gooding Lecture at the Divinity School of the University of Chicago in 1969.

Chapter 4, 'Emptiness', is from Our Religions, ed. Arvind Sharma (San Francisco: HarperSan Francisco, 1993), pp. 114-24.

Chapter 5, 'God, Emptiness, and the True Self', appeared in The Eastern Buddhist, 11/2 (1969), pp. 15-30; and in The Buddha Eye, ed. Frederick Franck (New York: Crossroad, 1982), pp. 61-74.

Chapter 6, The Concept of Self as Reflected in Zen Buddhist Literature', appeared in Wind Bell, 22/1 (1988), pp. 3-9.

Chapter 7, 'Education in Zen', appeared in The Eastern Buddhist, 9/2 
(1976), pp. 64-70, based on a paper delivered at the World Congress on Buddhism and the Modern World held at Dongguk University in Seoul, Korea in September 1976. The author is grateful to Mr and Mrs Peter Schneider for their revision of the manuscript.

Chapter 8, 'Substance, Process, and Emptiness: Aristotle, Whitehead, and Zen', appeared in Japanese Religions, 11/2-3 (1980), pp. 3-34.

Chapter 9, The Problem of Death in East and West: Immortality, Eternal Life, Unbornness', appeared in The Eastern Buddhist, 19/1 (1986), pp. 30-61, trans. David Dilworth, based on a paper originally published in Japanese in the journal Zengaku kenky $\bar{u}$ (Studies in Zen Buddhism), 51 (1961), pp. 88-112. The author is grateful to Professor Dilworth and to Professor Christopher A. Ives and Professor Paul L. Swanson for their valuable suggestions in the final stages of manuscript preparation.

Chapter 10, Sūnyatā as Formless Form: Plato and Mahāyāna Buddhism', appeared in Avaloka, 11/1 (1987), pp. 22-9.

Chapter 11, The Self in Jung and Zen', The Eastern Buddhist, 18/1 (1985), pp. 57-70; and in Self and Liberation: The Jung/Buddhism Dialogue, ed. David J. Meckel and Robert L. Moore (New York: Paulist Press, 1992), pp. 128-40.

Chapter 12, 'Time in Buddhism' was previously unpublished.

Chapter 13, 'On the Occasion of Buddha Day 1990: The Future Task of Buddhism', Pacific World, 7 (1991), 96-9, based on a lecture at the University of California at Berkeley in May 1990.

Chapter 14, Transformation in Buddhism', appeared in BuddhistChristian Studies, 7 (1987), pp. 5-24, based on a paper delivered at the second Buddhist-Christian Theological Encounter at Vancouver School of Theology, March 1985. The author is grateful to Professor Samuel I. Shapiro for his revision and valuable suggestions.

Chapter 15, 'Religious Tolerance and Human Rights: A Buddhist Perspective', appeared in Religious Liberty and Human Rights in Nations and Religions, ed. Leonard Swidler (Philadelphia: Ecumenical Press, 1986), pp. 193-211.

Chapter 16, 'Shinto and Buddhism: The Two Major Religions of Japan', appeared in the Scottish Journal of Religious Studies, VIII/1 (1987), pp. 53-63.

Chapter 17, 'Zen in Japan', is from Zen in China, Japan, East Asian Art, eds H. Brimlar, R. P. Kramus, C. Ouwehand (Berne: Peter Lang, 1984), pp. 47-64.

Chapter 18, 'The Japanese View of Truth', appeared in Japanese Religions, 14/3 (1986), pp. 1-6. 
We thank the following parties for permission to reprint this material: the editor of The Eastern Buddhist for Chapters 1, 5, 7, 9, 11 (also the Nanzan Institute for Chapter 5 and Paulist Press for Chapter 11); the editor of Criterion for Chapter 3, HarperSan Francisco for Chapter 4; the editor of Wind Bell for Chapter 6; the editor of Japanese Religions for Chapters 8 and 18; the editor of Avaloka for Chapter 10; the editor of Pacific World for Chapter 13; the editor of BuddhistChristian Studies for Chapter 14; Leonard Swidler for Chapter 15; the editor of Scottish Journal of Religious Studies for Chapter 16; and Peter Lang Publishers for Chapter 17. (Chapters 2 and 12 were previously unpublished.)

Finally, as in the case of editing Buddhism and Interfaith Dialogue, I greatly appreciate the efforts of the editors at Macmillan, and I am especially thankful for the opportunity to assist Masao Abe in the collection and dissemination of his eminently valuable work on Zen Buddhist and comparative studies. 


\section{Preface}

Not relying on words or letters,

An independent self-transmitting apart from any teaching;

Directly pointing to the human Mind,

Awakening one's Original Nature, thereby actualizing

Buddhahood.

This expression, attributed to Bodhidharma, captures the fundamental significance of Zen theory and practice in the context of Buddhist thought and the field of religion in general. Almost all forms of Buddhism, especially in East Asia, rely on a certain sütra or scripture as the source of truth. According to this standpoint, that which has no basis in scriptural authority cannot be called truth. Thus, almost all forms of Buddhism may be referred to as schools of 'Buddha's word.' By contrast, Zen does not rely on words or letters and directly points to one's mind as the universal Buddha Mind, and that is why Zen has sometimes been referred to as the school of 'Buddha mind.' This implies that Mind is self-transmitting independent of any particular sütra or doctrinal teaching.

Due to this trans-linguistic, trans-scriptural character, the notion of 'comparative studies' with regard to Zen may seem quite alien. However, in the modern age, comparative studies is extremely important in understanding the nature of world philosophy of religion, and this approach can and must also be applied to an elucidation of Zen. The traditional Zen standpoint beyond words should be framed and analyzed in light of cultural history and comparative philosophy. The title of this collection of essays, which I wrote over a period of two decades, highlights the sharp contrast and conflict as well as the areas of compatibility and complementarity between Zen and comparative studies. In Part One, Fundamentals of Zen, I elucidate the meaning of Zen as a self-transmission of mind in its own terms. These essays take up the topics of 'ordinary mind is Tao,' life and death and good and evil, emptiness, selfhood, and education. On the other hand, in the essays in Part Two, Zen, Buddhism, and Western Thought, I situate Zen in a comparative philosophical context thought discussions of the Aristotelian notion 
of Substance, Whitehead's notion of process, and Plato's idea of Form (eidos). Focusing on the problem of death, the article on "The Problem of Death in the East and West' tries to elucidate the essential characters of Platonism, Christianity and Buddhism, especially Zen, through a systematic comparative approach.

In Part Three, Current Issues in Buddhism, I pick up a number of contemporary topics such as monotheism versus monism, time and self, human rights and religious tolerance from the angle of comparative studies. Finally, Part Four, Zen and Japanese Culture, attempts to clarify the role of Zen in terms of the intellectual history of Japan from ancient literature and Tokugawa Shinto thought to modern philosophy. 